\title{
Regulation of Purkinje Cell Alignment by Reelin as Revealed with CR-50 Antibody
}

\author{
Takaki Miyata, ${ }^{1,2,3}$ Kazunori Nakajima, ${ }^{1}$ Katsuhiko Mikoshiba, ${ }^{1,3, a}$ and Masaharu Ogawa ${ }^{2, a}$ \\ ${ }^{1}$ Molecular Neurobiology Laboratory, Tsukuba Life Science Center, The Institute of Physical and Chemical Research \\ (RIKEN), Tsukuba, Ibaraki 305, Japan, 2Department of Physiology, Kochi Medical School, Nankoku, Kochi 783, Japan, \\ and ${ }^{3}$ Department of Molecular Neurobiology, Institute of Medical Science, University of Tokyo, Minato-ku, \\ Tokyo 108, Japan
}

\begin{abstract}
Cerebellar Purkinje cells are generated in the ventricular zone, migrate outward, and finally form a monolayer in the cortex. In reeler mice, however, most Purkinje cells cluster abnormally in subcortical areas. Reelin, the candidate reeler gene product recognized by the CR-50 monoclonal antibody, is concentrated in a cortical zone along which Purkinje cells are aligned linearly, implying that it may regulate their alignment. We used an in vitro system and a transplantation approach to analyze the function of Reelin.

Explant culture for $7 \mathrm{~d}$ of cerebella isolated from wild-type and reeler mice at embryonic day 13 (E13) reproduced in a phenotype-dependent manner the two distinct arrangement patterns (linear vs clustered) of Purkinje cells. Extensive CR-50 binding to wild-type explants converted the linear pattern into a reeler-like, clustered pattern. On the other hand, when reeler explants lacking Reelin were crowned with an artificial layer of
\end{abstract}

Reelin ${ }^{+}$granule cells, some Reelin molecules were distributed into a superficial zone of the reeler explants, and Purkinje cells formed a linear pattern along the Reelin-rich overlay. This "rescue" effect was also inhibited by CR-50. Hence, Reelin is involved in the Purkinje cell alignment, and the lack of this activity may explain the malformation in reeler cerebella.

We further injected Reelin ${ }^{+}$granule cells into the fourth ventricle of E12-13 mice. Extensive incorporation of the injected Reelin ${ }^{+}$cells into the ventricular zone, but not of Reelin ${ }^{-}$ cells, forced Purkinje cells of the host cerebella to form an aberrant layer, suggesting that premigratory Purkinje cells may already be responsive to Reelin or Reelin-related signals.

Key words: cerebellum; layer formation; cell migration; reeler mutant mouse; reelin; CR-50; Purkinje cell; granule cell; explant culture; transplantation
In the developing cerebellum, young Purkinje cells migrate radially from the ventricular zone toward the pial surface (Sidman and Rakic, 1973; Altman and Bayer, 1985; Yuasa et al., 1991). It is unclear how these Purkinje cells form their layer (Rakic, 1990; Hatten and Heintz, 1995). The reeler mouse mutant (Falconer, 1951; for review, see Caviness and Rakic, 1978; Goffinet, 1984, 1995; Rakic and Caviness, 1995) is useful for studying this unknown cytoarchitectural mechanism, because most Purkinje cells in the cerebellum of reeler mice are not arranged in the monolayer as observed in the cerebellar cortex of normal mice but are instead clustered in subcortical areas (Mariani et al., 1977; Mikoshiba et al., 1980; Goffinet, 1983; Yuasa et al., 1993) (Fig. 1A-C). Studies with normal-reeler chimeras have demonstrated that some of the Purkinje cells that are genetically reeler can be positioned nor-

\footnotetext{
Received Dec. 14, 1996; revised Feb. 10, 1997; accepted Feb. 24, 1997.

This work was supported by the Ministry of Education, Science, Sports and Culture of Japan (a Grant in Aid for Scientific Research on Priority Areas on "Functional Development of Neural Circuits"), the Science and Technology Agency of the Japanese Government, and CREST (Core Research for Evolutional Science and Technology) of Japan Science and Technology Cooperation (J.S.T.). T. M. was supported by the Narishige Neuroscience Research Foundation. We thank Drs. G. D'Arcangelo and T. Curran for their helpful comments on this work, and Drs. C. Lambert and A. M. Goffinet for their unpublished data. We also thank members of Division of Experimental Animal Research of RIKEN for their help to maintain mice, Dr. M. Niinobe for anti-MAP2, Dr. J. Aruga for anti-zic, and Dr. M. Watanabe for anti-spot35/calbindin.

Correspondence should be addressed to Takaki Miyata, Department of Molecular Cellular, and Developmental Biology, Campus Box 347, University of Colorado at Boulder, Boulder, CO 80309-0347.

a These authors contributed equally to this work.

Copyright (C) 1997 Society for Neuroscience 0270-6474/97/173599-11\$05.00/0
}

mally, and conversely, Purkinje cells of normal origin are found ectopically (Mullen, 1978, 1984; Terashima et al., 1986), suggesting that a cue(s) governing the normal alignment of Purkinje cells is extrinsic to Purkinje cells.

The CR-50 monoclonal antibody, generated by immunizing reeler mice with normal embryonic brain cells, recognizes specific CNS regions of normal mice during development, but not those of reeler mice (Ogawa et al., 1995). Its antigen is localized to the regions that are affected in reeler mice, and the mRNA of reelin, the candidate reeler gene, is expressed (D'Arcangelo et al., 1995; Hirotsune et al., 1995; Schiffmann et al., 1997). Moreover, CR-50 recently has been shown to recognize the Reelin protein itself (D’Arcangelo et al., 1997; C. Lambert and A. M. Goffinet, personal communication). Therefore, the role of CR-50 antigen can now be interpreted in terms of the function of Reelin. CR-50 immunohistochemistry on the developing cerebellum of normal mice (Miyata et al., 1996) shows that Reelin is produced by a proportion of non-Purkinje neurons (deep nuclear neurons before inward migration and granule cells) between embryonic day (E) 13 and around postnatal day (P) 14. Reelin is extracellularly presented in cortical zones [initially throughout the external granular layer (EGL) and then the premigratory zone (PMZ), consisting of the inner half of EGL and the molecular layer (ML)] (Fig. $1 D$ ), along which Purkinje cells are arranged during this period. Such distribution raised a possibility that this molecule might act as an extrinsic cue that would regulate the arrangement of Purkinje cells.

To examine this possibility, we used an explant culture system 


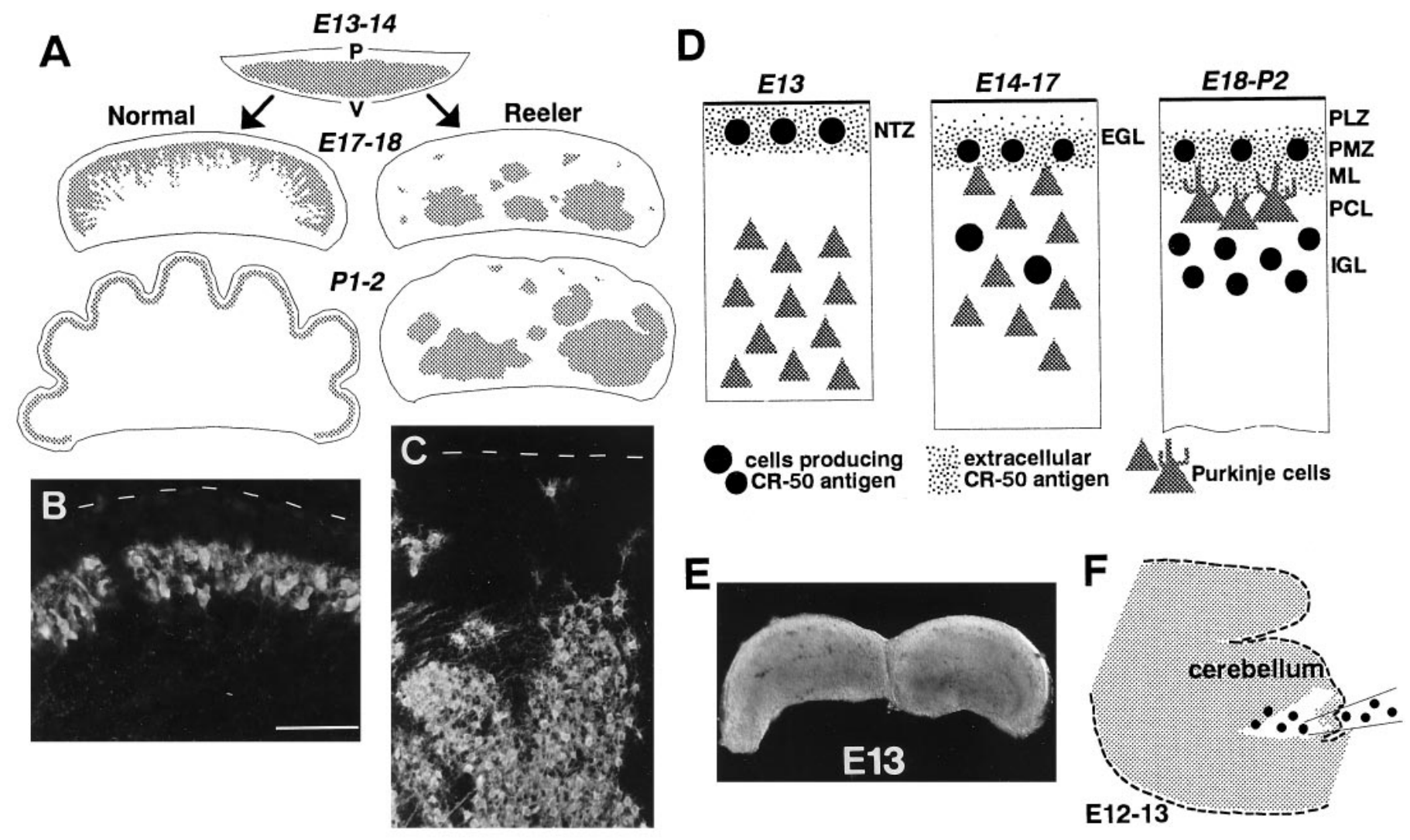

Figure 1. Experimental design to study the possible involvement of Reelin/CR-50 antigen in the arrangement of Purkinje cells. $A$, Schematic illustration showing behaviors of Purkinje cells (shaded) in vivo. In normal mice, Purkinje cells generated in a zone along the ventricular surface $(V)$ migrate radially and then accumulate at superficial cortical areas near the pial surface $(P)$ and form Purkinje cell layer $(P C L$; also see $D)$. In reeler mice, however, Purkinje cells remain as clusters at deep cerebellar areas. $B, C$, Anti-calbindin immunostaining on sagittal cerebellar sections of normal $(B)$ and reeler $(C)$ mice at P2. Broken lines indicate the pial surface. Calbindin ${ }^{+}$Purkinje cells are distributed distinctly between the two phenotypes. $D$, Spatiotemporal distributions of CR-50 antigen in the cerebellum of normal mice (Miyata et al., 1996). The molecule is produced by non-Purkinje neurons and presented extracellularly at the deeper half of the external granule layer $(E G L)$, along which Purkinje cells are aligned, and not detected in reeler mice. $E$, Cerebellar explant isolated from E13 mice and mounted in collagen gel. $F$, Injection of granule cells into the fourth ventricle of E12-13 mouse embryos. Scale bar: $B, C, 50 \mu \mathrm{m} ; E, 750 \mu \mathrm{m}$. NTZ, Nuclear transitory zone; $P L Z$, proliferative zone; $P M Z$, premigratory zone; $M L$, molecular layer; $I G L$, internal granular layer.

(Fig. $1 E$ ) in which embryonic Purkinje cells are positioned in a phenotype-dependent manner, and tested a possible blocking effect of CR-50 on the alignment of Purkinje cells in wild-type explants. Conversely, the effect of Reelin was also examined by coculture of reeler-derived explants with Reelin ${ }^{+}$granule cells. Furthermore, by grafting the Reelin ${ }^{+}$granule cells into embryonic cerebella, especially into the ventricular zone (Fig. $1 F$ ), the responsiveness of Purkinje cells in vivo was examined. Our results suggest that Reelin plays an important role in the alignment of Purkinje cells.

\section{MATERIALS AND METHODS}

Animals. B6C3Fe-a/a-rl mice (heterozygous for the reeler mutation) were obtained from the Jackson Laboratory. Homozygous animals to be used at embryonic and early postnatal days were generated by pairing homozygotes, and wild-type $\mathrm{B} 6 \mathrm{C} 3 \mathrm{Fe}$ mice at the corresponding stages were used as controls. For staging, E0 was defined as the day of vaginal plug identification, and the day of birth was indicated as P0.

Explant culture. Timed-pregnant mice were killed with an overdose of ethyl ether. Embryos at E13 were removed from the uterus, and their heads were cut off in dishes containing PBS $(-)$. Cerebellar anlage was isolated by dissecting the metencephalic region and was freed from meninges and transferred into another dish containing culture medium. Then, hemicerebella that were cut off at the midline or unseparated bilateral cerebella (either of which brought the same results) were transferred individually by a micropipette onto a base layer of collagen gel in 35-mm-diameter Petri dishes (Falcon). The base layer ( $\sim 1 \mathrm{~mm}$ high) was reconstituted previously from an acid collagen solution (Cellmatrix I, Nitta Gelatin, Japan) according to the manufacturer's protocol. After culture medium was removed, cerebellar explants were covered with an overlay $(\sim 0.5 \mathrm{~mm}$ high) of collagen gel matrix. The explants were positioned to the top of the overlay so that the upper surface of the explants was almost exposed to air, or they were covered with a small amount of collagen, oriented with the pial side at the top and the ventricular side at the bottom.

After incubation at $37^{\circ} \mathrm{C}$ in $5 \% \mathrm{CO}_{2}$ for $30 \mathrm{~min}, 500 \mu \mathrm{l}$ of culture medium, DMEM/F12 medium (Life Technologies, Gaithersburg, MD) supplemented with 5\% fetal calf serum and 5\% horse serum, was added to the dishes. The same culture medium at $5 \times$ concentration was used for preparing the gel matrix. The size of each explant (Fig. $1 E$ ) was $\sim 2 \mathrm{~mm}$ long (from lateral edges to the midline), $1 \mathrm{~mm}$ wide (rostrocaudal length), and $0.3-0.4 \mathrm{~mm}$ high. In the starting E13 explants [staged as zero day in vitro (DIV)], CR $-50^{+}$cells were localized along the pial surface, and immature Purkinje cells were near the ventricular surface, as demonstrated previously (Miyata et al., 1996). Viability of explants was monitored under phase-contrast microscopy, based on the presence of neurite extension, which indicated healthy growth. When E12 cerebella were used, the differences in Purkinje cell arrangement between normal and reeler groups (see Results) were observed less clearly than in E13 explants. Explants prepared later than E13 (examined with those at E14, E15, and E16) showed the phenotype-dependent patterns of Purkinje cell arrangement more evidently than those from E13, but their responses to treatments for blocking and rescue decreased.

In blocking experiments, CR-50 purified from ascites fluid was added 
to culture from the first day at a concentration of $0.5-2.0 \mathrm{mg} / \mathrm{ml}$. Fab fragments were prepared as described earlier (Ogawa et al., 1995) and were used similarly. IgG fractions from nonimmune reeler mice were used as a control. Of the antibody- or Fab-treated explants, $>95 \%$ grew well and were used to analyze the internal structures. Blocking of the arrangement of Purkinje cells in cerebellar explants required CR-50 at a higher concentration than that used for reaggregate culture of cerebral cortical cells $(0.2-1.0 \mathrm{mg} / \mathrm{ml})$ (Ogawa et al., 1995). This may reflect a more continuous generation of Reelin-producing cells, or a relatively low accessibility of CR-50 to explants, compared with gradually enlarging cerebral cortical cell aggregates, in which only the earliest generated Cajal-Retzius neurons provide Reelin and the antibody could react to small cell clusters.

For coculture experiments, granule cells were enriched from the cerebella of normal mice at $\mathrm{P} 4-8$, principally according to a previously described method (Hatten, 1985). In brief, after a single-cell suspension was preplated on polyethylenimine $(0.1 \%$; Sigma, St. Louis, MO)-coated flasks (Falcon) at $37^{\circ} \mathrm{C}$ for $40 \mathrm{~min}$, unbound cells were collected and separated into large and small cell fractions on a $60-35-0 \%$ Percoll (Pharmacia) step gradient. In the small cell fraction, $>95 \%$ of cells were of round morphology typical of granule cells. Immunohistochemically (see below), $\sim 80 \%$ of these small cells were positive with anti-zic (Aruga et al., 1994) (see Fig. 4R,U) and anti-microtuble-associated protein 2 (anti-MAP2) (Niinobe et al., 1988), and they were also stained with CR-50 in normal mice (see Fig. 4E,H,J,L) but not in reeler mice (see Fig. $4 S, V)$. Cells stained with anti-glial fibrillary acidic protein (anti-GFAP) were $<1 \%$ of the total, and large-sized calbindin ${ }^{+}$cells were almost excluded (see Fig. $4 A-D)(0.01-0.02 \%) ; 2$ or $3 \mu \mathrm{l}$ of such purified small cell suspension $\left(7-8 \times 10^{7} \mathrm{cells} / \mathrm{ml}\right)$ was transferred, by glass capillaries connected to a microsyringe, to the surface of cerebellar explants prepared 2-3 $\mathrm{hr}$ before (see Fig. $4 F$ ). Each explant was estimated to be covered by $\sim 1-2 \times$ $10^{5}$ cells.

To assess the reproducibility of in vivo histogenesis and the effects of antibodies or cocultured cells on explants, we characterized explants by calculating the frequencies of occurrence of "patterns" shown in lowpower (10× objective lens) microphotographs of 5-10 sections (per hemicerebellar explant) that contained many calbindin ${ }^{+}$Purkinje cells (exemplified in Figs. 2-4). Each explant often had two or three patterns among these sections, and even one of the sections occasionally showed combined patterns. In bar graphs in Figures 2-4, therefore, the percentage of explants showing one of the patterns is presented independent of that for other patterns, and the sum of the percentages exceeds $100 \%$.

In utero transplantation. We modified previously described methods for transplantation into rat embryos (Brüstle et al., 1995; Campbell et al., 1995). Granule cells enriched as described above but labeled with $0.01 \%$ 1,1'-dioctadecyl-3,3,3',3'-tetramethylindocarbocyanine perchlorate (DiI; Molecular Probes, Eugene, OR) during a preincubation period before fractionation with Percoll were suspended in HBSS at a density of $0.7-1.0 \times 10^{8}$ cells $/ \mathrm{ml}$. Pregnant female mice with embryos at E12-13 were anesthetized with pentobarbital $(0.06 \mathrm{mg} / \mathrm{gm})$, and a midline laparotomy was performed. Uterine sacs were exposed and transilluminated to identify the fourth ventricle, which is margined by blood-rich choroid plexus tissue, or the mesencephalic vesicle of each embryo. Then, $1-2 \times$ $10^{5}$ cells $(1.5-2.0 \mu \mathrm{l}$ of the cell suspension) were injected directly into the fourth ventricle or through the mesencephalic aqueduct. The injection was performed free-hand using a $10 \mu \mathrm{l}$ Hamilton syringe equipped with a glass micropipette with a 50-60 $\mu \mathrm{m}$ outer diameter generated from hematocrits capillary tubes (Drummond) by a micropipette puller (Narishige, Tokyo, Japan). The injection was completed within 1-2 sec, and the capillary was pulled out after a delay of 3-4 sec. Injected animals were placed back into the abdominal cavity for spontaneous delivery. A total of 189 embryos were injected, and $77(41 \%)$ survived into the postnatal period and were analyzed further. By counting CR $-50^{+}$or $\mathrm{zic}^{+}$cells found in a ventricular area where DiI was distributed (in most cases DiI dispersed from granule cell bodies to their processes, and therefore counting by only DiI staining was difficult) (Fig. 5), we found 20 cerebella that showed "extensive" incorporation of granule cells (approximately $>100$ grafted cells per $16 \mu \mathrm{m}$ section spread over a $>100 \mu \mathrm{m}$ distance along the lateral-to-medial axis occupying the ventricular zone, and the original tissue such as the cerebellar nuclei filled with calbindin ${ }^{+}$fibers originating from Purkinje cells were compressed). In most of the host cerebella analyzed at the second postnatal week $(>22 \mathrm{~d}$ after transplantation), grafted granule cells derived from normal mice continued to be stained with CR-50, even though for the grafted cells the days of analysis corresponded to ages older than P26-30, when CR-50 immunoreactivity has been already lost in vivo (Miyata et al., 1996). Similar persistent expression was observed in granule cells cultured in monolayers.

Immunohistochemistry. Explants at 7 DIV were fixed by immersion in periodate-lysine-paraformaldehyde (PLP) fixative (McLean and Nakane, 1974) at $4^{\circ} \mathrm{C}$ for $1 \mathrm{hr}$. They were then immersed in $20 \%$ sucrose, embedded in O.C.T. compound (Miles), frozen, and serially sectioned (16 $\mu \mathrm{m})$ across the long (lateral-to-medial) axis. Postnatal cerebella after transplantation were fixed by transcardial perfusion with PLP as described (Miyata et al., 1996) and sectioned sagittally $(16 \mu \mathrm{m})$. Serial sections covering the entire explant or cerebellum were collected sequentially onto five to nine slides. Therefore, each slide had a set of sections at separate planes in steps of $80-150 \mu \mathrm{m}(10-15$ sections from a hemicerebellar explant or 20-35 sections from a transplanted cerebellum). After they were rinsed, sections were reacted with antibodies diluted in PBS containing Triton X-100 (0.01\%) and sodium azide $(0.02 \%)$ for $2 \mathrm{hr}$ at room temperature, or overnight at $4^{\circ} \mathrm{C}$. So that DiI could be visualized after immunostaining, sections were permeabilized by a freeze-thaw method (Temple and Davis, 1994), omitting Triton X-100 from the diluent. The primary mouse monoclonal antibodies used were anticalbindin D (1:200; BioMakor), anti-nestin (hybridoma supernatant; Miyata and Ogawa, 1994) and CR-50 (20-40 $\mu \mathrm{g} / \mathrm{ml}$, purified from ascites fluid; Ogawa et al., 1995), which were visualized with fluorescein isothiocyanate (FITC)-labeled anti-mouse IgG (1:100; Vector Laboratories, Burlingame, CA). For staining of the extracellular Reelin, cerebellar explants were reacted with CR-50 (100-200 $\mu \mathrm{g} / \mathrm{ml}$ in culture medium) for 1-3 $\mathrm{hr}$ before fixation. Sections were also stained with either of the following polyclonal antibodies: anti-MAP2 (1:1000), anti-zic (1:100), anti-spot35/calbindin (Yamakuni et al., 1984) (1:2000; gift from Dr. M. Watanabe at Hokkaido University), anti-type-I inositol 1,4,5trisphosphate receptor (anti-IP3R, 1:500; Maeda et al., 1989), or antiGFAP (1:10; BioGenex), each of which was followed by anti-rabbit IgG conjugated to tetramethylrhodamine isothiocyanate (TRITC) or FITC (1:100; Cappel, West Chester, PA). Sections of explants that had been exposed to bromodeoxyuridine (BrdU) in vitro $(10 \mu \mathrm{M}$ in culture medium) or transplanted cerebella after BrdU injection on E11 or E12 or both $(0.1 \mathrm{mg} / \mathrm{gm}$ body weight of pregnant mice $)$ were stained with rat monoclonal anti-BrdU (1:20; BIOSYS), according to a previously described procedure (Soriano and Del Rio, 1991). In blocking experiments, sections of explants treated with CR-50 at a high $(>1 \mathrm{mg} / \mathrm{ml})$ concentration were stained with anti-calbindin after a preincubation with nonlabeled anti-mouse IgGs to lessen the overlap of anti-calbindin immunoreactivity with that of tissue-bound CR-50, or stained with anti-IP3R. Immunolabeling was analyzed using an epifluorescence microscope (Olympus, BX-50). Photographs were taken on T-Max p3200 black and white film (Kodak) or Fujichrome 400 color film (Fuji).

\section{RESULTS}

\section{Cerebellar explants derived from wild-type and reeler mice reproduce the in vivo cytoarchitectural events}

Initial cerebellar explants isolated from wild-type and reeler mice at E13 were indistinguishable by gross morphology. In phasecontrast microscopic observation, these two types of explants in collagen gel grew similarly until fixation at 7 DIV. By this culture time, they were enlarged horizontally with a 1.5 -fold increase in their upper surface area. In serial sections, the maximal thickness (distance between the ventricular and pial surfaces) of the fixed explants was not different between the normal and reeler groups (0.4-0.6 $\mathrm{mm}$ in both) (Fig. 2) and was larger than that of the initial explants $(0.3-0.4 \mathrm{~mm})$ but smaller than that of the in vivo cerebellum at P1-2 (0.9-1 mm in normal mice and $0.7-0.8 \mathrm{~mm}$ in reeler mice). Structures corresponding to folia and fissures were not recognized in both groups.

To examine whether the distinct cerebellar phenotypes (Fig. $1 A-C$ ) were reproduced in vitro, the distribution of Purkinje cells was examined by immunohistochemistry against calbindin (Jande et al., 1981; Wassef et al., 1985) (Fig. 2A-H). The relative number of Purkinje cells, examined by anti-calbindin staining of cells dissociated enzymatically from explants, was comparable between the normal and reeler explants. Among cross sections of both types of explants, four "patterns" were recognized (illustrated in Fig. 2I; 

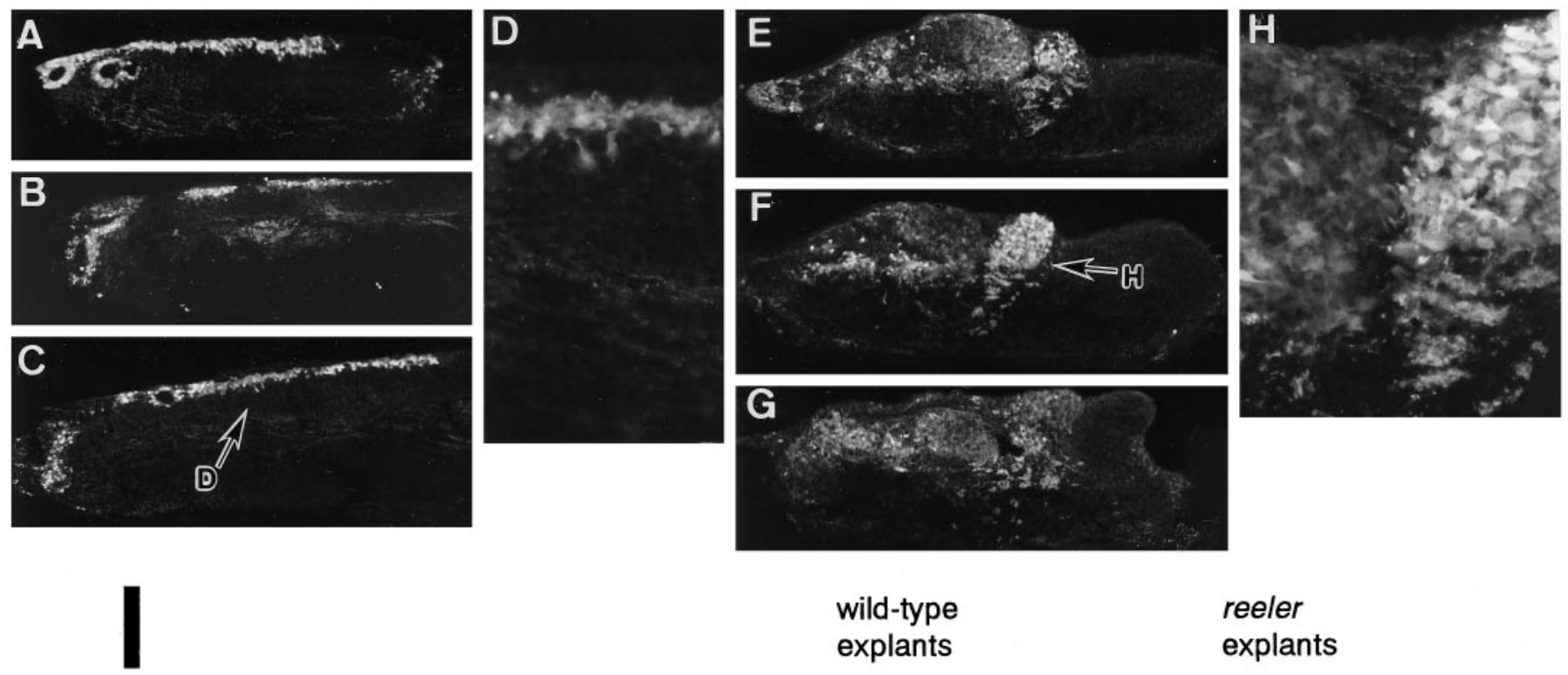

wild-type

explants

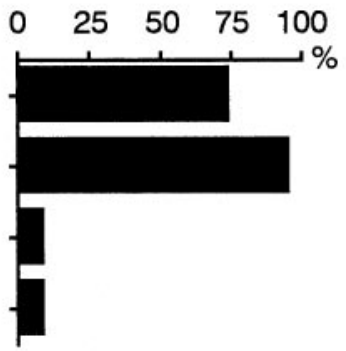

$\mathrm{n}=23$ reeler

explants

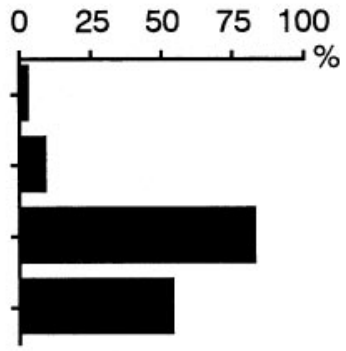

$\mathrm{n}=35$
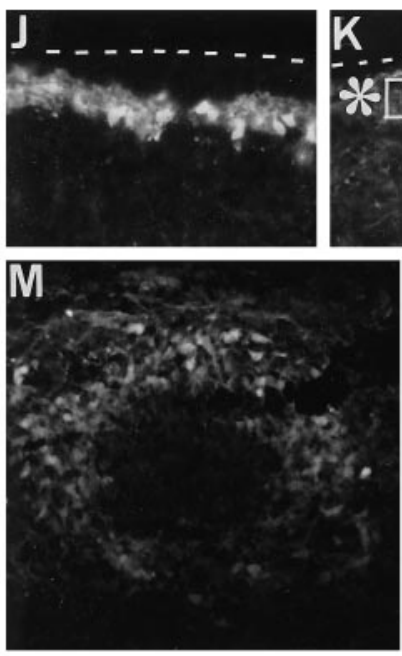
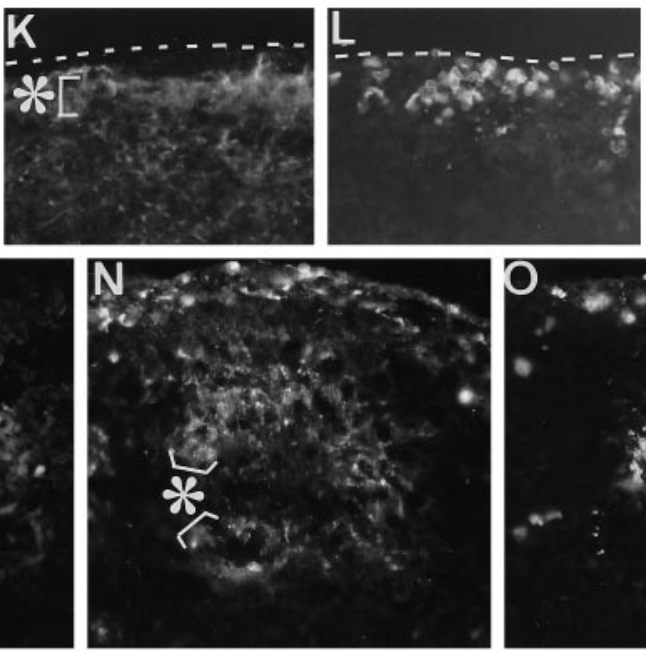
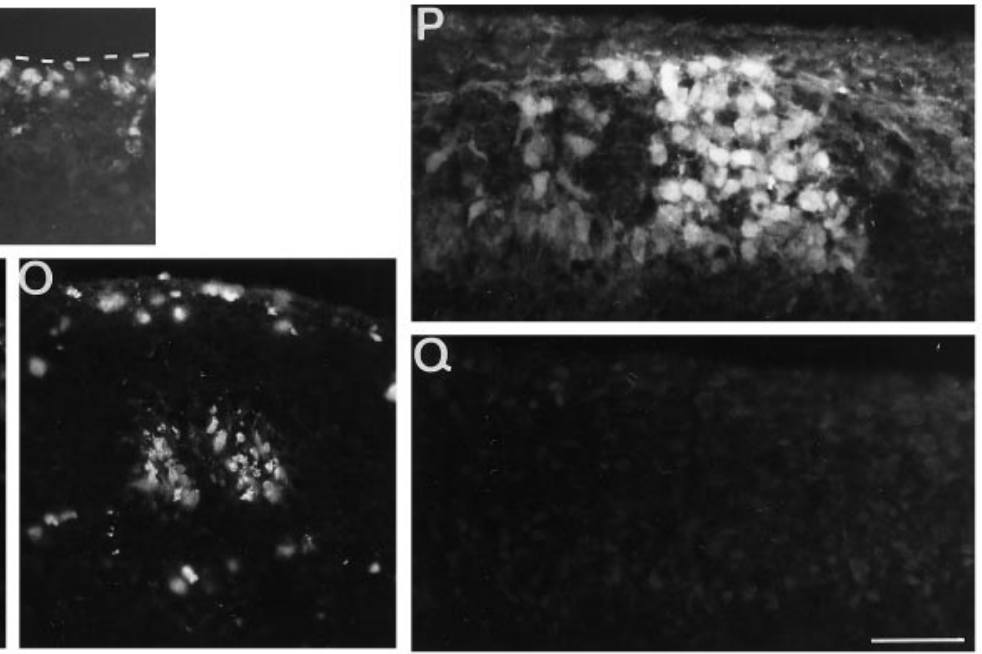

Figure 2. Untreated cerebellar explants derived from normal and reeler mice. Explants fixed at 7 DIV were sectioned across the long axis and stained with anti-calbindin. Sets of photomicrographs show distinct distribution patterns of Purkinje cells between a normal-derived explant $(A-D)$ and a reeler-derived explant $(E-H) . D$ and $H$ are magnified views of the indicated portion in $C$ and $F$, respectively. $I$, Histograms showing the frequencies of occurrence of four "patterns" (vertical axis; also illustrated schematically on the left), which were extracted from photomicrographs of 10-15 separate sections covering the entire explants, in normal and reeler explants. For example, the wild-type case in $A-D$ shows "straight lines" $(A-D)$ and "turned lines" or "loops" $(A, B)$, whereas the reeler case in $E-H$ shows "clusters" $(F, H)$ and a "diffuse" pattern $(E, G)$. One explant often had two or three patterns among the sections, and even one of the sections occasionally showed combined patterns. Therefore, the percentage for one of the patterns is calculated and presented independent of that for the remaining patterns, and the sum of the percentages exceeds $100 \%$. $J-Q$ are magnified views of superficial areas in explants (same magnification), and they show the spatial relationship between Purkinje cells and other layer-like structures identified in vitro. $J-O$, Sets of photomicrographs showing the relationships between calbindin ${ }^{+}$Purkinje cells $(J, M)$, extracellular Reelin/CR-50 antigen (asterisks in $K$ and $N$ ), and cells taking up $\operatorname{BrdU}(L, O)$ around the "straight line" $(J-L)$ and "loop" $(M-O)$, two PCL-like structures in wild-type explants. The wild-type explants were exposed to BrdU for $1 \mathrm{hr}$ before fixation, and serial sections were stained with antibodies to these markers. In both structures, there was a lamination sequence from a layer or mass of cells taking up $\operatorname{BrdU}(L, O)$ to the "straight line" $(J)$ or "loop" $(M)$ formed by Purkinje cells, through an extracellularly CR-50 immunoreactive zone $(K, N)$, which often overlapped the Purkinje cells. Broken lines in $J-L$ indicate the upper (pial) (Figure legend continues) 

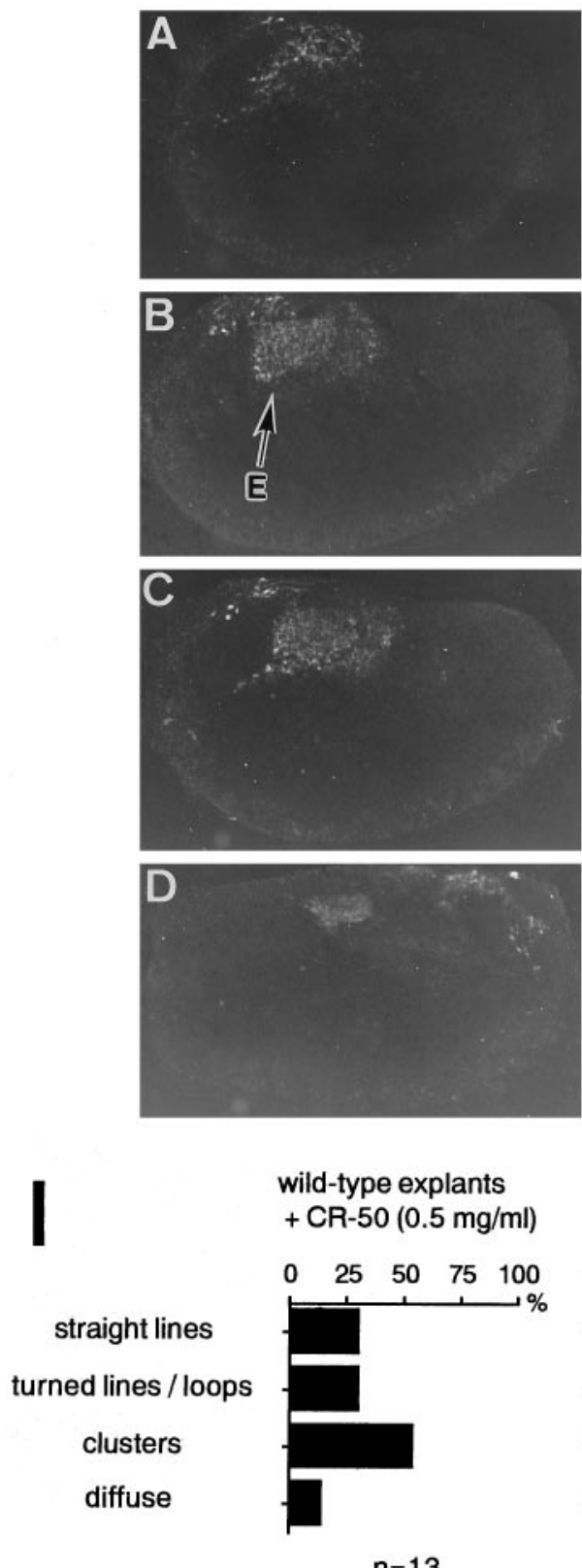

$n=13$
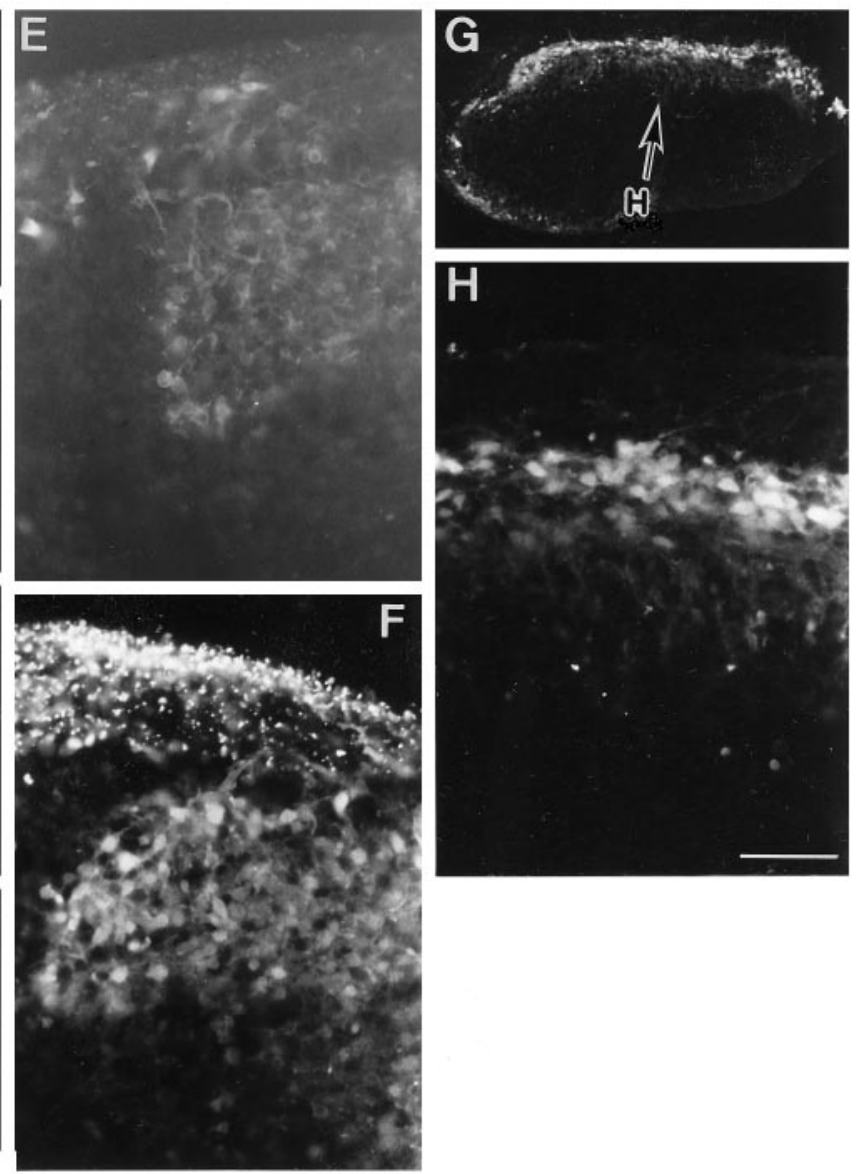

wild-type explants + CR-50 (2 mg/ml)

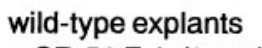

+ CR-50 Fab (2 mg/ml)

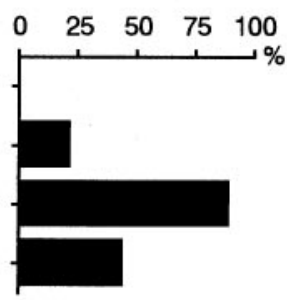

$\mathrm{n}=9$

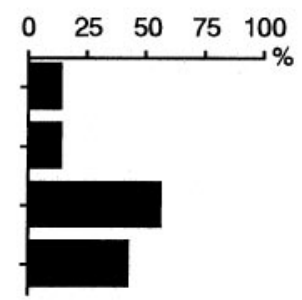

$\mathrm{n}=7$ wild-type explants + reeler $\operatorname{lgG}(2 \mathrm{mg} / \mathrm{ml})$

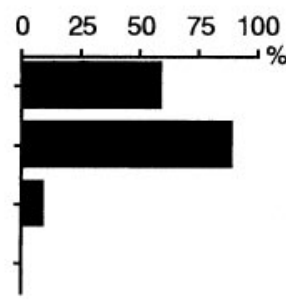

$n=10$

Figure 3. Wild-type explants exposed to CR-50 and control IgG. Purkinje cells were identified with rat anti-type-I IP3R ( $A-E)$ or mouse anti-calbindin $(F-H)$ monoclonal antibody at 7 DIV. In CR-50-exposed explants $(A-F)$, Purkinje cells were found as clusters (the indicated site in $B$ is magnified in $E)$, which resembled those found in explants from reeler mice (also see Fig. $2 H, P$ ). In the control explants $(G, H)$, Purkinje cells showed "straight lines" as observed in nontreated wild-type explants (compare with Fig. $2 A-D$ ). In $F$, a section adjacent to that shown in $E$ was treated only with anti-calbindin, but tissue-bound CR-50 was visualized simultaneously with anti-mouse secondary antibody as fine puncta among the superficial zone above the clustered Purkinje cells. Scale bar: E, F, H, $50 \mu \mathrm{m} ; 200 \mu \mathrm{m}$ in the remaining photographs. Graphs in $I$ show the frequencies of occurrence of the four "patterns" explained in Figure 2 and indicate that the blocking effect of CR-50 was reproduced by Fab treatment.

see also Materials and Methods). Although each explant often showed two or three patterns and even one of the sections occasionally had combined patterns, we were able to characterize these explants by calculating the frequencies of occurrence of these "patterns."

In most explants isolated from normal mice (Fig. $2 A-D$ ), Pur- kinje cell bodies gathered as either or both of the following two types of "lines": (1) almost straight lines (74\%) along or below the upper surface of the explants and (2) curved lines (96\%) that were often U-shaped or ring-like in appearance and continued to the "straight lines." In these calbindin ${ }^{+}$lines, the stratification of Purkinje cells did not exceed five cells in thickness. This was

surface of explants. CR-50 immunoreactivity other than the bands (asterisk) in $K$ and $N$ seems to correspond to granule neurons labeled intracellularly. $P, Q$, Double staining with anti-calbindin $(P)$ and CR-50 $(Q)$ on reeler explants, in which Purkinje cells were clustered $(P)$ and Reelin was not detected $(Q)$. Scale bar: $A-C, E-G, 200 \mu \mathrm{m} ; D, H, J-O, 50 \mu \mathrm{m}$. 

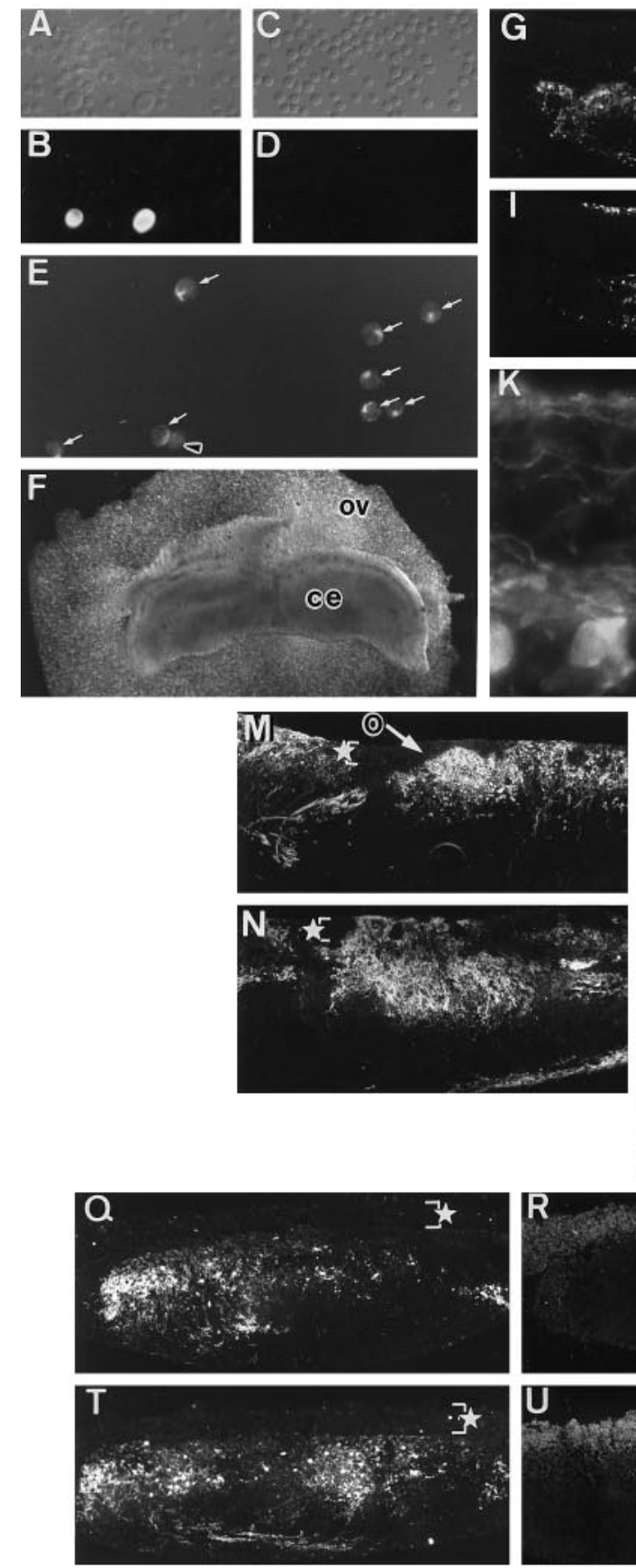

W

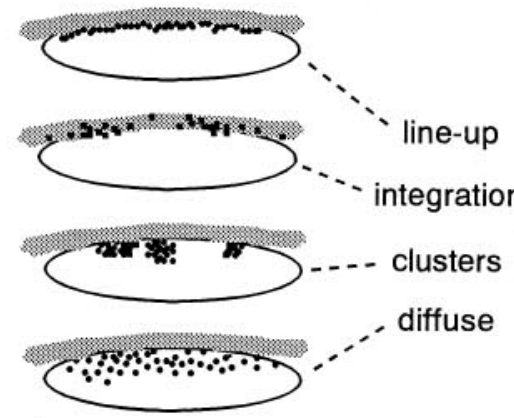

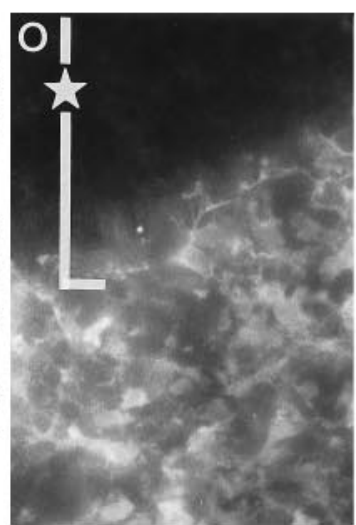
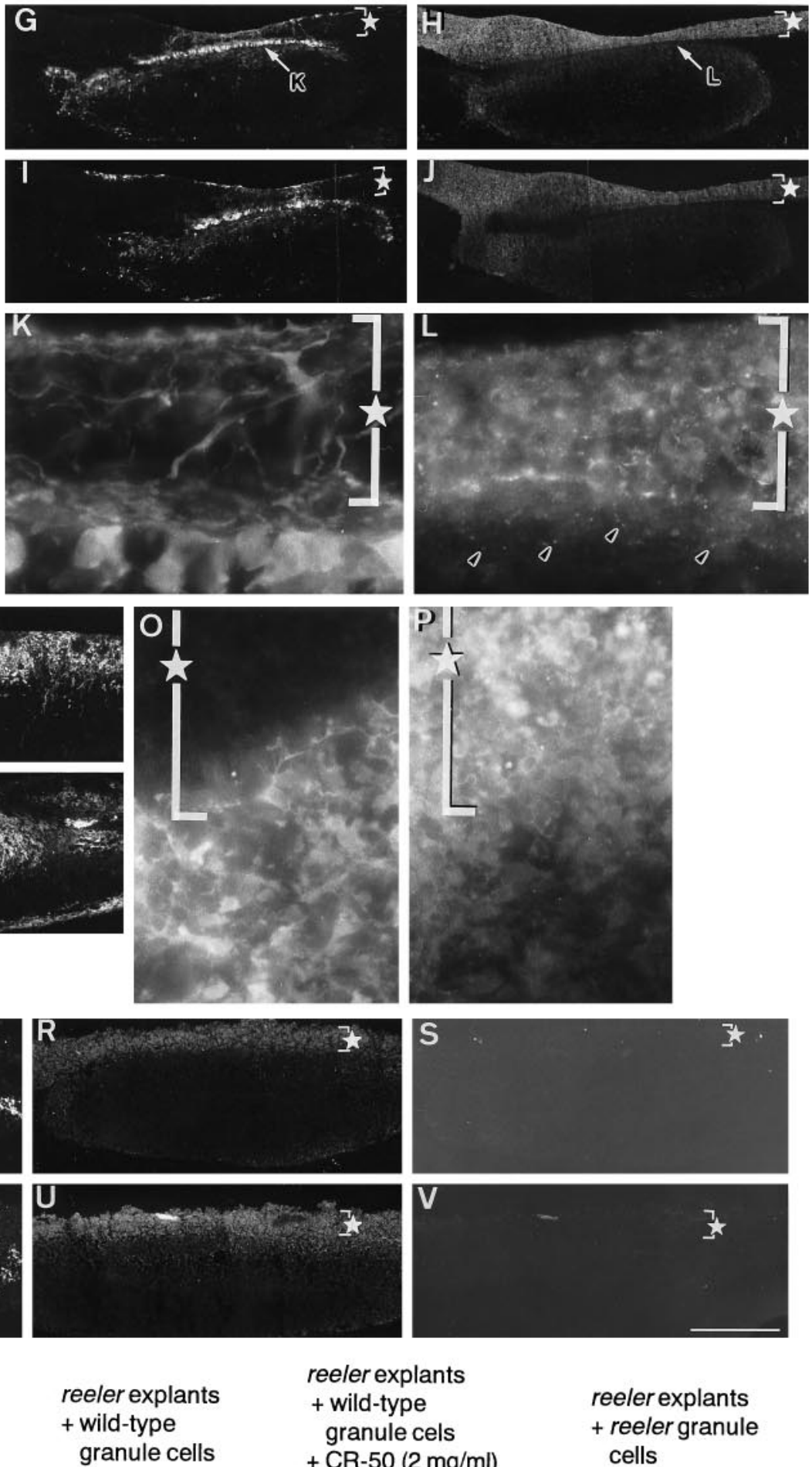

\section{reeler explants}

+ wild-type granule cels + CR-50 (2 mg/ml)

reeler explants + reeler granule cells

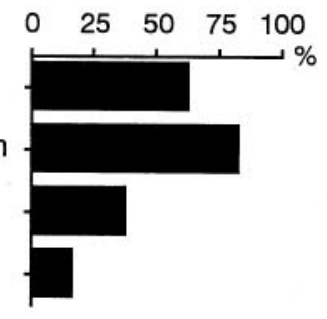

$n=24$

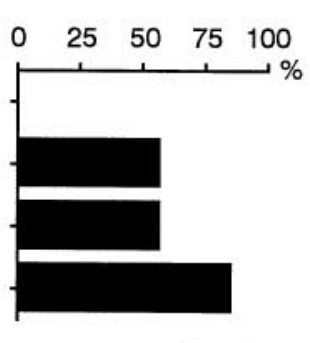

$n=7$

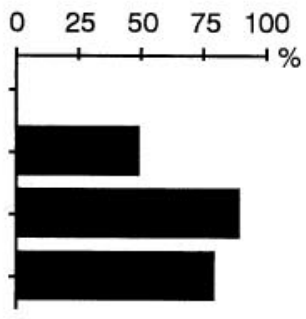

$\mathrm{n}=10$ 
similar to that of the in vivo Purkinje cell layer (PCL) at perinatal days. Below these "lines," axon-like fibers positive for calbindin ran parallel or obliquely to the upper surface of the explants. In contrast, Purkinje cells in explants derived from reeler mice (Fig. $2 E-H)$ formed "clusters" consisting of up to 50 cells per $100 \mu \mathrm{m}$ square $(83 \%)$ and/or a "diffuse" pattern $(54 \%)$, and some of these Purkinje cells were often located in deep areas among which axon-like structures were found. These results suggest that explants derived from mice of either phenotype preserve the presence and the absence of a mechanism(s) by which Purkinje cells behave distinctly in vivo.

Additional immunohistochemical analysis (Fig. 2J-O) was performed to examine the relationships of the PCL-like structures in normal-derived explants to other cells or molecules comprising the in vivo cerebellar cortex. The PCL at early postnatal days is overlaid with the following layers (Fig. 1D): (1) the "proliferative zone" (PLZ) (Altman, 1972), which is the most superficial layer occupying the outer half of EGL, (2) the PMZ, and (3) the ML. Patterns of immunoreactivity similar to these layers that may be identified with specific antibodies in vivo were observed in vitro. Extracellular Reelin/CR-50 antigen, which is concentrated in PMZ and ML in vivo (Miyata et al., 1996), were detected in explants isolated from normal mice and formed several patterns of lines (Fig. $2 K, N$ ). These lines resembled, in shape and route, the calbindin ${ }^{+}$lines described above, and in many cases overlapped them (Fig. 2J,M). Explants from reeler mice were CR-50negative (Fig. 2Q). The relative positions of proliferating cells were determined by BrdU labeling of normal-derived explants for $1 \mathrm{hr}$ before fixation and subsequent anti-BrdU immunostaining. Nuclei labeled with BrdU were found along the almost straight line-up of Purkinje cells (Fig. $2 L$ ) or as aggregates in the centers of the hair pin-like structures or "loops" composed of Purkinje cells (Fig. 2O). In cases in which such $\mathrm{BrdU}^{+}$cell groups were not close to Purkinje cells, the sandwiched zone showed extracellular CR-50 immunoreactivity (Fig. $2 N$ ).

These findings suggest that the sequence of layering in the in vivo cerebellar cortex, from PLZ to PCL through PMZ and ML, which are both labeled with CR-50, is reproduced in explants isolated from normal mice. The "loop" and "turned line" patterns of extracellular
CR-50 immunoreactivity probably reflect invaginations of proliferative granule cells and the subsequent surrounding by differentiated granule neurons, which produce Reelin and present it extracellularly (Miyata et al., 1996). The spatial relationship between the extracellular Reelin and the PCL-like structures in vitro indirectly suggests the importance of this molecule in the alignment of Purkinje cells.

\section{CR-50 converts the arrangement of normal-derived Purkinje cells into a reeler-like pattern}

When cerebellar explants isolated from normal mice were cultured in medium containing CR-50 (Fig. $3 A-F, I$ ), the majority of Purkinje cells showed "clustered" or "diffuse" patterns similar to those observed in explants from reeler mice (Fig. $2 E-H$ ). Both patterns were observed at a slightly lower frequency in these CR-50-exposed explants than those in reeler explants, but at a much higher frequency than in cultures with control IgGs (Fig. $3 G, H)$. This effect was reproduced with the application of Fab fragments of CR-50 (Fig. 3I). Linear patterns, which were observed in most of the normal-derived explants that were untreated or in those with control IgGs, were found only in less than one third of the CR-50-exposed ones. Within the superficial areas below which Purkinje cells were often clustered, tissue-bound CR-50 was strongly stained by treatment with only secondary antibody as immunoreactive puncta (Fig. $3 F$ ), similar to in vivo observations (Miyata et al., 1996). The distribution of Purkinje cells in explants derived from reeler mice was not influenced by CR-50 treatment (data not shown). These results indicate that CR-50 binding to the extracellular Reelin in normal-derived explants may affect positioning of the Purkinje cells oriented toward the superficial areas in which these cells should form "line" patterns.

\section{Purkinje cells in reeler explants are arranged along an overlay filled with Reelin}

The effect of exogenous Reelin on the arrangement of Purkinje cells in reeler explants was tested. Granule cells, which have been found to produce this molecule and to present it on their surface until approximately P14 (Miyata et al., 1996), were purified from cerebella of normal mice at $\mathrm{P} 4-8$ according to a previously

\footnotetext{
$\leftarrow$

Figure 4. Reeler explants cocultured with granule cells. Cerebella of normal mice were dissociated at P4-8 $(A, B)$, and granule cells were enriched $(C$, $D)$, as described in Materials and Methods. Anti-calbindin staining $(B, D$; phase-contrast views of the same fields are shown in $A$ and $C)$ showed that Purkinje cells (two labeled cells in $C$ ) were excluded. By CR-50 staining $(E)$, most of the enriched cells with round shape were positive (arrows); only one cell in this field (arrowhead) is CR-50-. These CR-50+ cells isolated from normal mice were also positive for zic, a marker of granule cells at this stage (Aruga et al., 1994) (not shown). F, With an overlay (ov) of such prepared normal-derived granule cells positive for Reelin/CR-50 antigen, cerebellar explants from reeler mice (ce) were crowned (a low-power phase-contrast view from the bottom of culture dish). $G-L$, An example of internal structures of reeler explants covered with the Reelin ${ }^{+}$granule cells, examined by staining with anti-calbindin $(G, I, K)$ and CR-50 $(H, J, L)$ at 7 DIV. Stars indicate the overlay. Reelin ${ }^{+}$cells were not found in explants, except for some areas in which the interface of the explants and overlays became ambiguous and the translocations of cells from each other were suggested $(I, J)$. Purkinje cells were aligned along (line-up) or integrated (integration) into (some cells are found at the top of the overlay) the Reelin ${ }^{+}$overlay. From the initial anti-calbindin staining of suspended cells for overlays, it was estimated that each overlay contained no more than 40 calbindin ${ }^{+}$Purkinje cells. Moreover, by monitoring of overlays placed on fixed cerebella or collagen gel, only two to three Purkinje cells were detected throughout $10-15$ planes chosen in steps of 100-120 $\mu \mathrm{m}$. Therefore, most if not all calbindin ${ }^{+}$cells found in the overlays covering reeler explants were considered to have come from the underlying reeler explants and are presented as integration. In cases in which cerebellar explants were prepared from reeler embryos after pulse labeling with BrdU on E11 and E12 in utero, the majority of calbindin ${ }^{+}$cells in the overlays were positive for BrdU (data not shown), also indicating that these cells may have migrated from the explants into the overlays. $K$ and $L$ are magnified views of the arrowed portions in $G$ and $H$, respectively, and show that extracellular Reelin was condensed in the overlay but also distributed in the underlying space (arrowheads). $M-P$, The effect of CR-50 on a reeler explant covered with normal-derived granule cells. Arrowed portion in $M$ is magnified in $O . P$ is a CR-50-stained section adjacent to $O$ and shows both intracellular labeling of overlying granule cells and extracellular binding of CR-50 during culture. Anti-calbindin staining $(M-O)$ showed "clusters" of Purkinje cells or "diffuse" pattern as observed in nontreated reeler explants. The "line-up" pattern was not observed, but some Purkinje cells were "integrated" into the overlay (stars) as observed in the absence of CR-50. $Q-V$, A reeler explant covered with Reelin ${ }^{-}$granule cells. Neighboring sections at two separate planes across the long axis of the explant were stained with anti-calbindin (left), anti-zic (middle), and CR-50 (right). Granule cells purified from reeler mice were not stained with CR-50, and overlays (stars) were identified by more intense labeling with anti-zic than explants containing endogenous zic ${ }^{+}$cells that were scattered throughout. Purkinje cells were distributed randomly and often "clustered" $(Q, T)$, as in untreated reeler explants. The results of all explants tested in these rescue experiments are presented in $W$. Scale bar: $A-D, 75 \mu \mathrm{m} ; E, O, P, 30 \mu \mathrm{m}, F, 1 \mathrm{~mm} ; G-J, M, N, Q-V, 300 \mu \mathrm{m} ; K, L, 20 \mu \mathrm{m}$.
} 

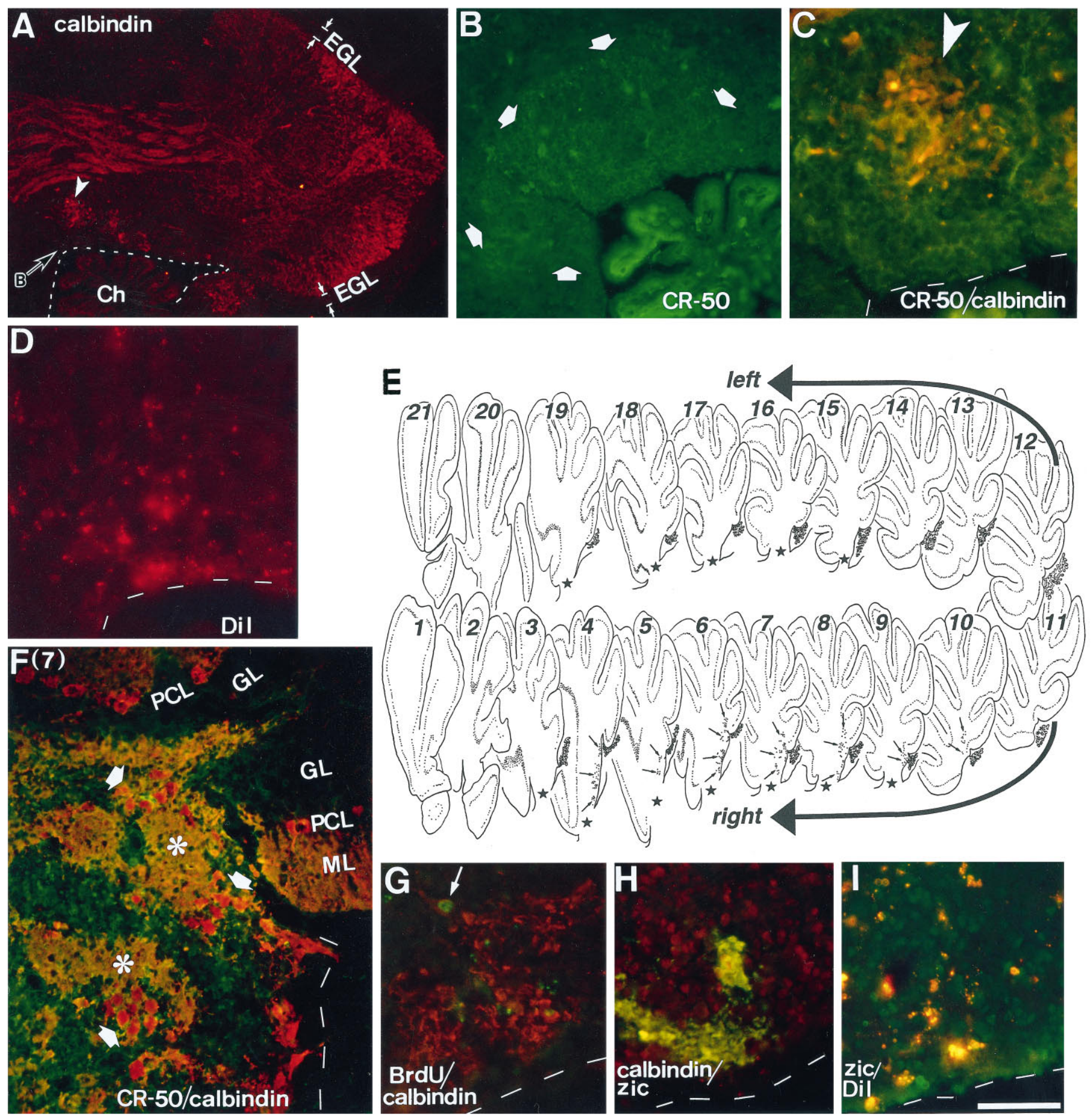

Figure 5. Effects of granule cell transplantation on embryonic Purkinje cells. Granule cells enriched as used for the overlays were labeled with DiI and injected into the fourth ventricle of wild-type mice at E13, as illustrated in Figure $1 F$. Broken lines in $A, C, D, F-I$ indicate the ventricular surface. Ch, Choroid plexus. $A-D$, Parasagittal sections of a wild-type host cerebellum fixed at P0. In sections that were double-stained with anti-spot35/calbindin (Yamakuni et al., 1984) $(A, C)$ and CR-50 $(B, C)$, most Purkinje cells were found in areas just below the external granular layer $(E G L)$, but some Purkinje cells (arrowhead) were found ectopically in an area facing the fourth ventricle. In the same ventricular area, CR-50 $0^{+}$cells formed a mass (thick arrows), although this area does not contain CR-50 ${ }^{+}$cells in untreated animals (Miyata et al., 1996). A view magnified further $(C$, double-exposed picture) shows that a group of Purkinje cells (the same arrowhead as in $A$ ) is surrounded by the CR-50+ cells. To confirm the origin of these CR-50 $0^{+}$cells, DiI was visualized in the adjacent section $(D)$. The pattern of DiI labeling matched the distribution of the CR-50 ${ }^{+}$cells along the ventricular surface. $E-I$, A wild-type host cerebellum that had been exposed to BrdU on E12 and fixed at P18. E is a set of traces of low-power photomicrographs of parasagittal sections stained with anti-spot35/calbindin, in which each dot represents one Purkinje cell. These sections were cut in steps of $120-150 \mu \mathrm{m}$ and cover the entire cerebellum, and the traces were processed and arranged using Superpaint 3.5J (Aldus). Almost all Purkinje cells were found in the cortex, but ectopic Purkinje cells (arrows) were also found in an area near the ventricular surface between the cerebellar peduncle (stars) and the site where choroid plexus begins, spreading over nearly $1 \mathrm{~mm}$ along the lateral-to-medial axis (from section 4 to 10). The corresponding but grafted cell-free area in the opposite side (sections 14-19) was empty of Purkinje cells. F, Photomicrograph of section 7, double-exposed for CR-50 (green) and anti-spot35 (red). In addition to Purkinje cells localized in the normal cortical positions [calbindin ${ }^{+}$cells comprising the Purkinje cell (Figure legend continues) 
described method (Hatten, 1985) (Fig. 4A-E), and reeler explants were covered with these cells (Fig. $4 F$ ). In these covered explants, the distribution of Purkinje cells at 7 DIV was distinct from that observed in uncovered reeler explants. Most remarkable was a lineup of Purkinje cell bodies along the granule cell overlays (Fig. $4 G, I)$. In magnified views, dendrite-like, thick processes extending from the soma of Purkinje cells were found to overlap the overlays filled with extracellular Reelin molecules identified as CR-50immunoreactive puncta (Fig. $4 K, L$ ). Such a relationship between Purkinje cells and Reelin was seen in both the ML of the in vivo cerebellar cortex (Miyata et al., 1996) and wild-type explants (Fig. $2 J, K)$. This pattern occurred only in reeler explants with overlays of Reelin ${ }^{+}$granule cells derived from normal mice $(65 \%)$ and not in reeler explants covered with Reelin ${ }^{-}$granule cells enriched from reeler mice (Fig. 4Q-V). Moreover, when the reeler explants with Reelin ${ }^{+}$overlays were exposed to CR-50, they did not show the "line-up" pattern (Fig. 4M-P). Thus, these coculture experiments suggest that Purkinje cells in the cerebellum of reeler mice can respond to Reelin or Reelin-related signals and form a layer in a manner similar to that seen in Purkinje cells in wild-type mice.

The reeler explants covered with normal granule cells often showed a pattern such that Purkinje cells were integrated into the overlays $(80 \%)$. This pattern was also found in some of the control explants with reeler-derived granule cells or when explants with normal granule cells were exposed to CR-50 (45\% and 50\%, respectively). This "integration" pattern may also reflect the migratory properties of Purkinje cells in vivo, but it could be explained by both Reelin-dependent and -independent mechanisms (discussed below).

\section{Premigratory Purkinje cells in vivo respond to transplanted Reelin ${ }^{+}$granule cells}

We next intended to determine when Purkinje cells become responsive to Reelin itself or Reelin-related signals in the developing cerebellum. One important time point to be tested would be days at which Purkinje cells are still in the ventricular zone. We therefore performed transplantation experiments in utero. To allow young Purkinje cells in the ventricular zone to contact with granule cells expressing Reelin, wild-type granule cells enriched as described above and further labeled with DiI were injected into the fourth ventricle of E12-13 mice. Reeler granule cells were also injected as a control. By microscopic analysis on sagittal cerebellar sections of 77 successfully born animals ranging from P0 to P18 at fixation, "extensive" (see Materials and Methods) incorporation of granule cells into the ventricular zone was found in 20 cerebella (Fig. $5 B-D, F, H$ ). The 20 cases were grafting of (1) wild-type cells into wild-type hosts ( $\rightarrow \mathrm{W}, n=6)$, (2) wild-type cells into reeler hosts $(\mathrm{W} \rightarrow \mathrm{R}, n=9)$, and (3) reeler cells into wild-type hosts $(\mathrm{R} \rightarrow \mathrm{W}$, $n=5)$. The degree of granule cell incorporation was similar between these three groups. The granule cells seemed to have been incorporated within a day after transplantation, suggesting that they may have contacted directly with immature Purkinje cells in the ventricular zone of the transplanted E12-13 cerebella.

Strikingly, most $(5 / 6)$ of the $\mathrm{W} \rightarrow \mathrm{W}$ cerebella clearly showed the effect of grafting; many Purkinje cells were localized in a region near the ventricular surface (Fig. $5 A, E, F$ ), where they are never found postnatally. These "ectopic" Purkinje cells were confirmed to be of the host origin by BrdU injection into operated females (Fig. $5 G$ ). As indicated by labeling on both E11 and E12 (twice a day), their labeling indices (70-90\%) were similar to those of Purkinje cells aligned in the cortex, whereas by labeling on E12 only, the ectopic cells were labeled at slightly higher indices $(50-60 \%)$ than those of the cortical Purkinje cells $(30-40 \%)$. The ectopic Purkinje cells formed small, layer-like structures with their cell bodies and dendrites and were surrounded by Reelin ${ }^{+}$. grafted cells (Fig. 5C,F). Although a similar coincidence between the incorporated Reelin ${ }^{+}$granule cells and calbindin ${ }^{+}$Purkinje cells was also seen in most (8/9) of the $\mathrm{W} \rightarrow \mathrm{R}$ cerebella (data not shown), we were not able to fully identify whether such a distribution pattern of Purkinje cells was a consequence of the grafting or simply an original, deranged pattern in the reeler cerebellum. On the other hand, ectopic Purkinje cells were not found in the $\mathrm{R} \rightarrow \mathrm{W}$ cerebella (data not shown). Thus, these transplantation experiments suggest that Reelin ${ }^{+}$but not Reelin ${ }^{-}$granule cells can force Purkinje cells to settle and form their layer prematurely before leaving the ventricular zone.

\section{DISCUSSION}

Using a culture system in which Purkinje cells of wild-type and reeler mice were positioned in phenotype-dependent manners (Fig. 2), we demonstrated an inhibitory effect of CR-50 on the normal arrangement of wild-type Purkinje cells (Fig. 3). Because CR-50 has been found to recognize Reelin (D'Arcangelo et al., 1997; C. Lambert and A. M. Goffinet, personal communication), this effect is interpreted to be caused by blocking of Reelin. We demonstrated further that Purkinje cells of reeler origin can respond to granule cells expressing Reelin with a "rescued" pattern of arrangement (Fig. 4). This rescue effect is considered to be of Reelin itself, because it also was blocked by CR-50. Thus, these blocking and rescue experiments support each other and together with the localization of Reelin in vivo (D'Arcangelo et al., 1995; Miyata et al., 1996) suggest strongly that Reelin is a crucial signal for the formation of PCL.

\section{Involvement of Reelin in the alignment of Purkinje cells}

Untreated wild-type and reeler explants yielded two remarkable findings (Fig. 2). First, Purkinje cells were positioned depending on their origin. This suggests that a mechanism(s) underlying their distinct alignment patterns in vivo is maintained in the explants. Second, the close spatial relationship between Purkinje cells and the extracellular Reelin in vivo was reproduced, even in complicated structures such as "turns" or "loops." These two findings indirectly supported our hypothesis that the extracellular Reelin might be essential to the formation of PCL.

More direct evidence was provided by experiments to manipulate the possible interaction between the extracellular Reelin and young Purkinje cells. Treatment with CR-50, probably leading to a significant loss of Reelin activity, caused Purkinje cells in wild-type explants to form reeler-type patterns (Fig. 3). In an attempt for gain-offunction, the majority of Purkinje cells in reeler explants took their

\footnotetext{
layer (PCL) and molecular layer (ML)], another population of Purkinje cells was found near the ventricular surface. The latter ectopic Purkinje cells were surrounded by CR-50 $0^{+}$cells and showed a layer-like pattern with their cell bodies (arrows) and dendrites (asterisks), which were sorted out from each other. Endogenous CR-50 immunoreactivity was already lost in the granular layer $(G L)$ of the host. $G$, Double staining with anti-BrdU (green) and anti-calbindin $($ red $)$. The arrowed nucleus is $\mathrm{BrdU}^{+}$, indicating that the ectopic Purkinje cell was generated in the host cerebellum on E12 (labeling indices were $\sim 50 \%$ in the ectopic Purkinje cells and $\sim 35 \%$ in PCL). H, Double staining with anti-calbindin ( green) and anti-zic (red). I, DiI (red) was visualized in an anti-zic (green)-stained section. Scale bar: $A, 200 \mu \mathrm{m} ; B, F, 100 \mu \mathrm{m} ; C, D, G-I, 50 \mu \mathrm{m}$.
} 
positions along an artificial layer filled with the extracellular Reelin (Fig. 4), as Purkinje cells in wild-type explants did along the endogenous Reelin ${ }^{+}$zone. This rescue effect was also blocked by CR-50. It is therefore likely that Reelin can regulate the alignment of Purkinje cells in the developing cerebellum. Furthermore, the present transplantation experiments provide evidence regarding the responsiveness of Purkinje cells. Reelin ${ }^{+}$but not Reelin ${ }^{-}$granule cells that were introduced into the ventricular zone seemed to force some of the host (wild-type) Purkinje cells to settle ectopically (Fig. 5). This suggests that before leaving the ventricular zone, young Purkinje cells are already responsive to Reelin itself or Reelin-related signals absent in reeler mice.

The fact, however, that some Purkinje cells in the cerebellum of reeler mice are arranged almost normally in the cortex (Mariani et al., 1977) implies the presence of mechanisms that are completely independent of Reelin. A portion of our results also suggest this possibility. In $50 \%$ of reeler explants covered with reeler-derived granule cells, Purkinje cells were found among the Reelin ${ }^{-}$granule cell overlay (integration, Fig. 4). This pattern was also observed when the explants covered with Reelin ${ }^{+}$granule cells were exposed to CR-50 (57\%), although the frequency of its occurrence was slightly lower than that without CR-50 (80\%). The translocation of Purkinje cells from reeler explants into the overlays of both origins might relate to Purkinje cell survival in the present culture condition, because previous cell-mixing experiments in monolayer culture demonstrated that interactions between Purkinje cells and granule cells are responsible for the survival and differentiation of Purkinje cells (Baptista et al., 1994). In addition, there might be an effect of mature (postnatal) granule cells on immature (embryonic) Purkinje cells in explants, and this could also explain a result of previous transplantation experiments (Sotelo and Alvarado-Mallart, 1986), in which E12 Purkinje cells injected into the cerebellum of adult Purkinje cell degeneration $(p c d)$ mutant mice were integrated into the ML after some migration from the grafted site. In our transplantation experiments, ectopic Purkinje cells were not seen in any of the five host (wild-type) cerebella that had reeler granule cell grafts (data not shown). Possibly, behaviors of Purkinje cells that would be Reelin-independent might have been detected more clearly in the explants with poorer conditions for cell survival than in vivo, or masked in the wild-type hosts by the endogenous Reelin itself or Reelin-dependent signals, with more significant effects.

\section{Possible roles of Reelin in the alignment of Purkinje cells}

The present rescue experiments indicate that in the presence of Reelin, reeler Purkinje cells can behave as Purkinje cells in nontreated wild-type explants. At the present time, this result could be explained by both a direct effect of Reelin on Purkinje cells and additional or alternative mechanisms that would be mediated indirectly by Reelin.

Immunohistochemical analysis on cerebellar cells at light microscopic level (Miyata et al., 1996) demonstrated two patterns of CR-50 immunoreactivity. Intracellular staining obtained after fixation and permeabilization indicates that stained cells (presumptive nuclear cells and granule cells) are producing Reelin. When vitally stained, the producer cells showed another pattern of (extracellular) immunoreactivity on their surface. When plasma membranes were prepared from perinatal cerebella or purified granule cells, CR-50 bound to these membranes. Because Reelin is a secreted protein (D'Arcangelo et al., 1997), the extracellular Reelin detected on the producer neurons and cerebellar mem- branes may correspond to the molecule that had been secreted and then held in some way on the surface of these producer neurons. Interestingly, the similar extracellular binding of CR-50 was detected on cell bodies and dendrites of Purkinje cells that are Reelin-negative intracellularly. Because it was not detected on Purkinje cell axons and non-neuronal cells identified with antinestin or anti-GFAP, it seems specific to the soma and dendrites of Purkinje cells. This implies further that Reelin molecules produced by non-Purkinje neurons might bind to a receptor-like molecule on Purkinje cells, either as a free secreted molecule or via direct contact between Purkinje cells and the non-Purkinje neurons presenting Reelin on their surface. Thus, there is a possibility that Reelin could act directly on Purkinje cells, but further analysis is needed.

In the point of view of the indirect effects of Reelin, the present results could be explained by a mechanism such that Reelin acts on its producer neurons in an autocrine fashion and the producer cells subsequently act on Purkinje cells in a Reelin-independent manner to allow them to take their appropriate positions. If Reelin is absent in such a situation, the subsequent loss of downstream events would lead to the reeler phenotype. In addition, a recent study focusing on radial glial cells in the neocortex suggests possible involvement of Reelin in the regulation of their shape or orientation (Hunter and Hatten, 1996). Reelin might regulate indirectly the migration and positioning of Purkinje cells through its effect on radial fibers in the developing cerebellum. In the present study, however, nestin ${ }^{+}$or $\mathrm{GFAP}^{+}$fibers were not distributed as straight, even in wild-type explants, and were not distinguishable between wild-type, reeler, and CR-50-exposed groups, or between explants with Reelin ${ }^{+}$overlays and those with Reelin ${ }^{-}$overlays (data not shown).

In the normal cerebellum, young Purkinje cells migrating outward may reach a zone (EGL) filled with the extracellular Reelin as early as E14 (Miyata et al., 1996) (Fig. 1D), when the first sign of Purkinje cell derangement is noted in reeler mice (Goffinet, 1983). Because the difference in the arrangement pattern of Purkinje cells between the two phenotypes is recognized clearly by late embryonic days (Yuasa et al., 1993) (Fig. 1A), and the following cerebellar development seems to amplify this difference, the initial relationships of Purkinje cells with Reelin itself or Reelin-related signals may be critical for their positioning. In the cerebellum of reeler mice lacking Reelin and the possible Reelin-dependent signals, young Purkinje cells would not be able to execute an active process to take a position just below the EGL. Consequently, a zone in which they should normally form their layer would be occupied by other cells, such as astroglial cells having migrated outwardly or descending granule cells. The reeler Purkinje cells would be deep in subcortical areas, away from the expanding cerebellar surface, with a clustered pattern probably attributable to their own homophilic adhesive properties and/or "obstruction" mechanisms (Pinto-Lord et al., 1982; Yuasa et al., 1993).

In summary, the present functional study reveals an important step downstream of reelin expression in cerebellar development. Because a recently reported mouse mutant, scrambler, of which the locus (chromosome 4) is different from that of reeler (chromosome 5), shows a reeler-like arrangement pattern of neurons (Goldowitz et al., 1996; González et al., 1996), it is possible that the scrambler gene may code a Reelin receptor. Our assays with cerebellar cells and CR-50 would be useful for assessing this possibility. In addition to its application in vitro (Ogawa et al., 1995; Del Río et al., 1997), CR-50 can be used for functional experiments in vivo (Nakajima et al., 1996). Further analysis at both molecular and cellular levels will lead to the total understanding of the roles of Reelin protein and the Reelin-mediated morphogenetic scenarios in developing brains. 
Note added in proof: Studies performed concurrently and independently with this work (by E. Y. Snyder in collaboration with our group), demonstrating that neural progenitors transplanted into the newborn reeler cerebellum may rescue certain aspects of mutant cytoarchitecture, lamination, and granule neuron survival by Reelin-dependent and Reelinindependent mechanisms, is now submitted and under review.

\section{REFERENCES}

Altman J (1972) Postnatal development of the cerebellar cortex in the rat. I. The external germinal layer and the transitional molecular layer. J Comp Neurol 145:353-398.

Altman J, Bayer SA (1985) Embryonic development of the rat cerebellum. I. Delineation of the cerebellar primordium and early cell movements. J Comp Neurol 231:1-26.

Aruga J, Yokota N, Hashimoto M, Furuichi T, Fukuda M, Mikoshiba K (1994) A novel zinc finger protein, zic, is involved in neurogenesis, especially in the cell lineage of cerebellar granule cells. J Neurochem 63:1880-1890.

Baptista CA, Hatten ME, Blazeski R, Mason CA (1994) Cell-cell interactions influence survival and differentiation of purified Purkinje cells in vitro. Neuron 12:243-260.

Bravin M, Rossi F, Strata P (1995) Different climbing fibres innervate separate dendritic regions of the same Purkinje cell in hypogranular cerebellum. J Comp Neurol 357:395-407.

Brüstle O, Maskos U, McKay RDG (1995) Host-guided migration allows targeted introduction of neurons into the embryonic brain. Neuron 15:1275-1285.

Campbell K, Olsson M, Björklund A (1995) Regional incorporation and site-specific differentiation of striatal precursors transplanted to the embryonic forebrain ventricle. Neuron 15:1259-1273.

Caviness Jr VS, Rakic P (1978) Mechanisms of cortical development: a view from mutations in mice. Annu Rev Neurosci 1:297-326.

D'Arcangelo G, Miao GG, Chen S-C, Soares HD, Morgan JI, Curran T (1995) A protein related to extracellular matrix proteins deleted in the mouse mutant reeler. Nature 374:719-723.

D'Arcangelo G, Nakajima K, Miyata T, Ogawa M, Mikoshiba K, Curran $\mathrm{T}$ (1997) Reelin is a secreted glycoprotein recognized by the CR-50 monoclonal antibody. J Neurosci 17:23-31.

Del Río JA, Heimrich B, Borrell V, Förster E, Drakew A, Alcántara S, Nakajima K, Miyata T, Ogawa M, Mikoshiba K, Derer P, Frotscher M, Soriano E (1997) A role for Cajal-Retzius cells and reelin in the development of hippocampal connections. Nature 385:70-74.

Falconer DS (1951) Two new mutants, "trembler" and reeler", with neurological actions in the house mice (Mus Musculus L.). J Genet 50:192-201.

Goffinet AM (1983) The embryonic development of the cerebellum in normal and reeler mutant mice. Anat Embryol 168:73-86.

Goffinet AM (1984) Events governing organization of postmigratory neurons: studies on brain developing in normal and reeler mice. Brain Res Rev 7:261-296.

Goffinet AM (1995) A real gene for reeler. Nature 374:675-676.

Goldowitz D, Laywell E, Steindler D, D’Arcangelo G, Sheldon M, Curran T, Davisson M, Johnson K, Sweet H (1996) Scrambler and reeler: morphomolecular analysis of mutant cerebella indicate one phenotype from two different genes. Soc Neurosci Abstr 22:961.

González JL, Russo C, Sweet H, Davisson M, Goldowitz D, Walsh C (1996) Neocortical birthdating analysis on scrambler, a novel mouse mutant, reveals a reeler-like phenotype. Soc Neurosci Abstr 22:987.

Hatten ME (1985) Neuronal regulation of astroglial morphology and proliferation in vitro. J Cell Biol 100:384-396.

Hatten ME, Heintz N (1995) Mechanisms of neural patterning and specification in the developing cerebellum. Annu Rev Neurosci 18:385-408.

Hirotsune S, Takahara T, Sasaki N, Hirose K, Yoshiki A, Ohashi T, Kusakabe M, Murakami Y, Muramatsu M, Watanabe S, Nakao K, Katsuki K, Hayashizaki Y (1995) The reeler gene encodes a protein with an EGF-like motif expressed by pioneer neurons. Nature Genet 10:77-83.

Hunter KE, Hatten ME (1996) A model for the differentiation and maintenance of the embryonic radial glial scaffold. Soc Neurosci Abstr 22:1206.

Jande SS, Maler L, Lawson DEM (1981) Immunohistochemical mapping of vitamin $\mathrm{D}$-dependent calcium-binding protein in brain. Nature 294:765-767.
Maeda N, Niinobe M, Inoue Y, Mikoshiba K (1989) Developmental expression and intracellular location of $\mathrm{P} 400$ protein characteristic of Purkinje cells in the mouse cerebellum. Dev Biol 133:67-76.

Mariani J, Crepel F, Mikoshiba K, Changeux JP, Sotelo C (1977) Anatomical, physiological and biochemical studies of the cerebellum from reeler mutant mouse. Philos Trans R Soc Lond [Biol] 281:1-28.

McLean IW, Nakane PK (1974) Periodate-lysine-paraformaldehyde fixative for immunoelectron microscopy. J Histochem Cytochem 22:1077-1083.

Mikoshiba K, Nagaike K, Kohsaka S, Takamatsu K, Aoki E, Tsukada Y (1980) Developmental studies on the cerebellum from reeler mutant mice in vivo and in vitro. Dev Biol 79:64-80.

Miyata T, Ogawa M (1994) Developmental potentials of early telencephalic neuroepithelial cells: a study with microexplant culture. Dev Growth \& Differ 36:319-331.

Miyata T, Nakajima K, Aruga J, Takahashi S, Ikenaka K, Mikoshiba K, Ogawa M (1996) Distribution of a reeler gene-related antigen in the developing cerebellum: an immunohistochemical study with an allogeneic antibody CR-50 on normal and reeler mice. J Comp Neurol 372:215-228.

Mullen RJ (1978) Genetic dissection of the CNS with mutant-normal mouse and rat chimeras. In: Society for Neuroscience, symposium 2 (Cowan WM, Ferrendelli JA, eds), pp 47-65. Bethesda: Society for Neuroscience.

Mullen RJ (1984) Ontogeny and genetics of the mammalian nervous system. In: Chimeras in developmental biology (LeDouarin N, McLaren A, eds), pp 353-368. London: Academic.

Nakajima K, Mikoshiba K, Miyata T, Kudo C, Ogawa M (1996) Disruption of hippocampal development in vivo by a CR-50 monoclonal antibody, which recognizes Cajal-Retzius neurons. Soc Neurosci Abstr 22:228.

Niinobe M, Maeda N, Ino H, Mikoshiba K (1988) Characterization of microtuble-associated protein 2 from mouse brain and its localization in the cerebellar cortex. J Neurochem 51:1132-1139.

Ogawa M, Miyata T, Nakajima K, Yagyu K, Seike M, Ikenaka K, Yamamoto H, Mikoshiba K (1995) The reeler gene-associated antigen on Cajal-Retzius neurons is a crucial molecule for laminar organization of cortical neurons. Neuron 14:899-912.

Pinto-Load MC, Evrard P, Caviness Jr VS (1982) Obstructed neuronal migration along radial glial fibers in the neocortex of the reeler mouse: a Golgi-EM analysis. Dev Brain Res 4:379-393.

Rakic P (1990) Principles of neural cell migration. Experimentia 46:882-891.

Rakic P, Caviness Jr VS (1995) Cortical development: view from neurological mutants two decades later. Neuron 14:1101-1104.

Schiffmann SN, Bernier B, Goffinet AM (1997) Reelin mRNA expression during mouse brain development. Eur J Neurosci, in press.

Sidman RL, Rakic P (1973) Neuronal migration, with special reference to developing human brain: a review. Brain Res 62:1-35.

Soriano E, Del Río JA (1991) Simultaneous immunocytochemical visualization of bromodeoxyuridine and neural tissue antigens. J Histochem Cytochem 39:255-263.

Sotelo C, Alvarado-Mallart RM (1986) Growth and differentiation of cerebellar suspensions transplanted into the adult cerebellum of mice with heredodegenerative ataxia. Proc Natl Acad Sci USA 83:1135-1139.

Temple S, Davis AA (1994) Isolated rat cortical progenitor cells are maintained in division in vitro by membrane-associated factors. Development 120:999-1008.

Terashima T, Inoue K, Yokoyama M, Mikoshiba K (1986) Observations on the cerebellum of normal-reeler mutant mouse chimera. J Comp Neurol 252:264-278.

Wassef M, Zanetta JP, Brehier A, Sotelo C (1985) Transit biochemical compartmentalization of Purkinje cells during early cerebellar development. Dev Biol 111:129-137.

Yamakuni T, Usui H, Iwanaga T, Kondo H, Odani S, Takahashi Y (1984) Isolation and immunohistochemical localization of a cerebellar protein. Neurosci Lett 45:235-240.

Yuasa S, Kawamura K, Ono K, Yamakuni T, Takahashi Y (1991) Development and migration of Purkinje cells in the mouse cerebellar primordium. Anat Embryol 184:195-212.

Yuasa S, Kitoh J, Oda S, Kawamura K (1993) Obstructed migration of Purkinje cells in the developing cerebellum of the reeler mutant mouse. Anat Embryol 188:317-329. 